\title{
Alat Permainan Edukatif Dalam Mengembangkan Kreativitas Musik Anak di Pendidikan Anak Usia Dini ‘Aisyiyah Terpadu Gantiwarno
}

\author{
NADIA AISYA ${ }^{1}$, NURUL AMELIA ${ }^{2}$ \\ Sekolah Tinggi Ilmu Tarbiyah Al Hikmah Tebing Tinggi Sumatera Utara \\ Email : nadiagumay7@gmail.com¹, nurulamel012@gmail.com²
}

\begin{abstract}
Abstrak : Alat permainan edukatif adalah alat yang dirancang dan dibuat, untuk menjadi sumber belajar anak-anak usia dini agar mereka mendapatkan pengalaman belajar yang bermakna, serta dapat menstimulasi perkembangan pada anak. PAUD Aisyiyah Terpadu Gantiwarno menciptakan alat permainan edukatif yang berbahan dasar dari sisa-sia barang bekas atau daur ulang yang mereka olah bersama-sama sehingga menghasilkan sebuah karya alat permainan edukatif yang dapat bermanfaat bagi anak-anak. Penelitian ini bertujuan untuk mendeskripsikan alat permainan edukatif dalam mengembangkan kreativitas musik anak di PAUD Aisyiyah Terpadu Gantiwarno. Metode Penelitian ini menggunakan metode kualitatif. Teknik pengumpulan data yang digunakan oleh peneliti dalam melakukan penelitian ini adalah obeservasi, wawancara, dokumentasi. Subyek dalam penelitian ini adalah anak-anak di PAUD Aisyiyah Terpadu Gantiwarno. Hasil yang diperoleh dalam penelitian ini antara lain: 1) guru dan anak-anak bersama-sama memanfaatkan bahan-bahan daur ulang sebagai alat permainan edukatif, 2) Pada proses kegiatan belajar anak-anak dalam menggunakan alat permainan edukatif kreativitas musik anak lebih cepat mengingat lagu-lagu, 3) anak-anak dapat mengekspresikan perasaan yang mereka rasakan baik sedih, gembira, dan takut melalui suara-suara yang dikeluarkan oleh alat musik, 4) Anak-anak dapat membuat alat perkusi dan dapat mengembangkan kreativitas dalam membuat lagu dan bermusik gaya pribadi. Selain itu dengan adanya permainan edukatif ini anak-anak lebih bersemangat dalam mengikuti kegiatan belajar.
\end{abstract}

Kata kunci: Alat Permainan Edukatif, Kreativitas Musik Anak, PAUD Aisyiyah Terpadu Gantiwarno Klaten

Abstract:Educational game tools are tools that are designed and created, to be a source of learning for young children so that they get a meaningful learning experience, and can stimulate development in children. PAUD Aisyiyah Terpadu gantiwarno created an educational game tool based on the remnants of used or recycled materials which they process together to produce an educational playground tool that can benefit children. This study aims to describe the educational game tools in developing children's musical creativity in PAUD Aisyiyah Terpadu Gantiwarno. This research method uses qualitative methods. Qualitative methods are used to describe events, people's behavior, or circumstances in the place that researchers use in conducting this research. Data collection techniques used by researchers in conducting this research are observation, interviews, documentation. The subjects in this study were children in PAUD Aisyiyah Terpadu Gantiwarno. The results obtained in this study include: 1) teachers and children jointly utilize recycled materials as an educational play tool, 2) In the process of children's learning activities in using educational play tools children's musical creativity is faster given songs, 3) children can express the feelings they feel good sad, happy, and scared through the sounds issued by musical instruments, 4) Children can make percussion instruments and can develop creativity in making songs and music personal style. In addition, with this educational game children are more excited in participating in learning activities.

Keywords: Educational Game Tools, Children's Music Creativity, PAUD Aisyiyah Terpadu Gantiwarno

PENDAHULUAN

Alat permainan adalah semua alat bermain yang digunakan anak untuk memenuhi naluri bermainnya. Peralatan tersebut tidak bisa dipisahkan dari kebutuhan anak. Macam alat permainan sebagai pelengkap untuk bermain sangat beragam. Ada yang bersifat bongkar pasang, 
mengkelompokkan,

memadukan,

mencari padanannya, merangkai, membentuk, menyempurnakan suatu desain, dan menyusun sesuai dengan bentuknya. Selagi bermain dengan alat permainan anak akan dapat memasukkan pengetahuan untuk anak ingat. Alat permainan merupakan bahan mutlak bagi anak untuk mengembangkan dirinya yang menyangkut seluruh aspek perkembangannya (Dwi Prasetiya, dkk, 2011).

Menurut suryadi (2007), bahwa manfaat permainan edukatif sebagai berikut: 1)Melatih kemampuan motorik. Stimulasi untuk perkembangan motorik dapat diperoleh saat meraba, menjumput maianan, memegang dengan kelima jarinya dan sebagainya. 2) Melatih konsentrasi. Permainan edukatif di rancang untuk melatih kemampuan konsentrasi anak dan menggali kemampuan anak 3)mengembangkan konsep sebabakibat. Misalnya memasukan benda kecil ke tempat besar sebab benda besar tidak bisa masuk ke dalam benda kecil. 4)Mengenal warna dan bentuk. Permainan yang beraneka ragam akan menstimulus anak dalam mengenal warna dan bentuk. 5)Menambah wawasan dan bahasa. Permainan edukatif akan menambah wawasan anak baik bentuk dan menumbuhkan bahasa dalam memainkannya (Syamsuardi, p.61).

Menurut Tedjasaputra Pengertian alat permainan adalah semua alat yang digunakan anak untuk memenuhi naluri bermainnya, sedangkan alat permainan edukatif adalah alat permainan yang sengaja dirancang secara khusus untuk kepentingan pendidikan (Syamsuardi, 2012). Alat permainan edukatif untuk anak TK adalah alat yang sengaja dirancang secara khusus untuk meningkatkan aspek-aspek perkembangan anak.

Menurut (Suryadi, 2007), bahwa alat permainan edukatif adalah alat yang dirancang khusus sebagai alat untuk bantu belajar dan dapat mengoptimalkan perkembangan anak, disesuaikan dengan usia dan tingkat perkembangannya.

Berdasarkan dari beberapa pendapat di atas dapat disimpulkan bahwa pengertian alat permainan edukatif adalah alat permainan yang sengaja dirancang secara khusus untuk mendukung aspek-aspek perkembangan anak yang disesusaikan dengan usia dan tingkat perkembangannya.

Kreativitas dalam bermusik adalah sebuah gaya fikir dan aktivitas seseorang dalam bermusik, dari 
PERNIK Jurnal PAUD, VOL 3 NO. 1 September 2020

aktifitas dan gaya berfikir tersebut maka seseorang mampu menghasilkan sebuah karya musik dan menganalisanya. Sehingga secara wujudnya proses kreativitas adalah berupa karya musik dan analisis musik (Milyartini, 2009). Kreativitas musik adalah kemampuan seseorang untuk mencipta lagu, instrument ataupun mengaransemen musik baru yang belum pernah diciptakan orang lain dan hasil lagu dan musiknya dapat dinikmati orang lain (Habsari).

Pada kegiatan bermusik, kreativitas memegang kunci utama ketika seseorang ingin menciptakan suatu karya yang orosinil, berbeda dan lebih maju dari yang sudah ada, serta dengan daya imajinasi yang harus berkembang, karena seseorang perlu bermain dengan gagasan dalam menginterpretasikan lagu. Hubungan antara kreativitas dengan musik sangat erat karena dengan aktivitas mencipta, mengaransemen atau bahkan menganalisis sebuah karya lagu, merupakan proses kreativitas oleh seseorang baik secara proses maupun produknya. Dengan kreativitaslah musik berperan menjadi musik yang utuh, tidak hanya berupa rangkaian nada-nada.

Kreativitas juga digunakan dalam pendidikan musik itu sendiri, dimana pendidikan musik yang kreatif bertujuan untuk mempermudah seseorang untuk mengerti dan memahami hal-hal yang terkandung dalam musik, baik secara teori maupun praktek. Namun berdasarkan pengamatan yang dilakukan oleh (Zujadi, p. 1) bahwa pengembangan kreativitas di tingkat pendidikan dasar dan menengah sangat kurang, hal ini disebabkan karena proses belajar mengajar (PBM) seni musik cenderung dilaksanakan secara teoritis, materi yang bersifat praktek sangat kurang.

Setelah beberapa penjelasan tersebut dapat disimpulkan bahwa sesungguhnya kreativitas dapat ditingkatkan melalui usaha-usaha pendidikan dan bimbingan. Hal ini berarti bahwa program pengembangan kreativitas yang disusun dengan baik, sistematis, teratur dilaksanakan secara kontinue dapat meningkatkan kreativitas anak, termasuk bagi anak usia dini. Berdasarkan obesrvasi yang saya lakukan pada tanggal 27 november 2018 pada kenyataannya peneliti menemukan banyaknya alat permainan edukatif terkait dalam mengembangkan kreativitas musik pada anak. Maka dari itu, peneliti tertarik untuk melakukan penelitian yang berjudul "Alat Permainan Edukatif Dalam 
Mengembangkan Kreativitas Musik

Anak di PAUD Aisyiyah Terpadu Gantiwarno".

\section{METODE PENELITIAN}

Metode penelitian yang digunakan peneliti dalam penelitian ini adalah kualitatif deskriptif. Kirk dan Miller (dalam Moleong, 2003) mendefinisikan penelitian kualitatif tradisi sebagai ilmu pengetahuan sosial yang secara mendasar bergantung pada pengamatan pada manusia dalam kawasannya sendiri dan berhubungan dengan orang-orang tersebut dalam bahasanya dan dalam peristilahannya. Fraenkel dan Wallen menyatakan bahwa penelitian yang mengkaji kualitas hubungan, kegiatan, dan situasi. Material penelitian kualitatif, dengan penekanan kuat pada deskripsi menyeluruh dalam menggambarkan rincian segala sesuatu yang terjadi pada suatu kegiatan atau situasi tertentu.

Lokasi penelitian ini dilakukan di PAUD Aisyiyah Terpadu Gantiwarno Klaten Tahun Ajaran 2018/2019. Adapun waktu penelitian dilakukan sejak tanggal 27 november 2018 sampai 30 november 2018. Sumber data dalam penelitian kualitatif meliputi sumber data primer dan sumber data sekunder.
Subjek penelitian ini adalah anak-anak di PAUD Aisyiyah Terpadu Gantiwarno Klaten, dan objek pada penelitian ini adalah kreativitas musik anak di PAUD Aisyiyah Terpadu Gantiwarno Klaten.

Adapun metode pengumpulan data yang penulis gunakan adalah metode observasi, wanwancara dan dokumentasi. Wawancara ditujukan kepada sumber data yang terlibat dalam kreativitas musik anak. Teknik wawancara yang dilakukan dalam penelitian ini adalah wawancara terstruktur dengan menyiapkan instrumen penelitian berupa pertanyaanpertanyaan tertulis. Sumber data dalam teknik wawancara adalah kepala sekolah, guru kelas, dan anak-anak di PAUD Aisyiyah Terpadu Gantiwarno Klaten. Kegiatan wawancara dilakukan di PAUD Aisyiyah Terpadu Gantiwarno Klaten dengan menggunakan pedoman wawancara yang disesuaikan dengan sumber dan peneliti. Dokumentasi yang digunakan dalam penelitian ini berupa foto anak ketika prose kegiatan belajar menggunakan alat permainan edukatif, video anak ketika menggunakan alat permainan edukatif, dan portofolio.

Uji ke absahan data, hal ini menunjukkan bahwa apa yang diamati peneliti sesuai dengan apa yang sesungguhnya ada dilokasi peneliti dan penjabaran dari deskripsi permasalahan 
sesuai dengan keadaan yang sebenarnya. Dengan menggunakan teknik triangulasi, teknik ini merupakan pemeriksaan keabsahan data dengan memanfaatkan sesuatu yang lain diluar data itu, untuk keperluan pengecekan atau sebagai pembanding terhadap data. Dalam penelitian ini kebenaran data menurut (Lexy J. Moleong, 2010) menggunakan tiga sumber yang berarti dalam penelitian ini membandingkan dan mengecek balik derajat kepecayaan suatu informasi yang diperoleh melaui waktu dan alat benda yang jalan:

1. Membandingkan hasil data dari pengamatan dengan hasil wawancara.

2. Membandingkan apa yang dikatakan orang-orang mengenai situasi penelitian dengan apa yang dikatakan setiap waktu.

3. Membandingkan apa yang dikatakan orang-orang didepan umum dengan apa yang informan katakan.

4. Membandingkan pandangan seseorang dengan berbagai pendapat dan pandangan orang seperti rakyat biasa, orang berpendidikan, orang pemerintahan dan sebagainya.

5. Membandingkan hasil wawancara dengan isi suatu dokumen secara berkelanjutan. Tujuannya jelas yaitu untuk bisa mengetahui alasan terjadinya perbedaan-perbedaan tidak hanya mengharap bahwa hasil perbandingan tersebut merupakan kesamaan pandangan, pendapat ataupun pemikiran.

Teknik analisis data yang digunakan dalam penelitian ini adalah analisis interaktif, yaitu bahwa ketiga komponen aktivitasnya berbentuk interaksi dengan proses pengumpulan data berbagai proses siklus. Analisis data dalam penelitian kualitatif dilakukan sejak sebelum memasuki lapangan, selama dilapangan dan setelah selesai dilapangan.

\section{HASIL PENELITIAN}

DAN PEMBAHASAN

\section{A. Deskriptif Data}

James J. Gallagher dalam (Yeni Rachmawati dan Euis, 2012) mengatakan bahwa "Creativity is a mental process by which an individual creates new ideas or products, or recombines existing ideas and product, in fashion that is novel to him or her" yang artinya kreativitas suatu mental yang dilakukan individu berupa gagasan ayaupun produk baru, atau mengombinasikan anatara keduanya yang pada akhirnya akan melekat pada dirinya. Lebih lanjut menurut (Supriadi, 1994) mengutarakan bahwa kreativitas adalah kemampuan seseorang untuk 
melahirkan sesuatu yang baru, baik berupa gagasan maupun karya nyata yang relatif berbeda dengan apa yang telah ada.

Selanjutnya ia menambahkan bahwa kreativitas merupakan kemampuan berfikir tingkat tinggi yang mengimplikasikan terjadinya eskalasi dalam kemampuan berfikir, di tandai oleh sukesi, diskontinuitas, dan integritas antara setiap tahap perkembangan. Clarkl Monstaiks (dalam Munandar, 1995) mengatakan bahwa kreativitas adalah pengalaman dalam mengerspresikan dan mengaktualisasikan identitas individu dalam bentuk terpadu antara hubungan diri sendiri, alam, dan orang lain.

Berdasarkan beberapa definisi di atas dapat kita simpulkan bahwa kreativitas adalah suatu proses mental individu yang melahirkan gagasan proses, metode, ataupun produk baru yang efektif yang berimajinatif, estetis, fleksibel, integrasi, sukesi, diskontinuitas, dan fiferensiasi yang berdaya guna dalam berbagai bidang untuk pemecahan suatu masalah. Musik adalah hasil karya seni bunyi dalam bentuk lagu atau komposisi musik yang mengungkapkan pikiran dan perasaan penciptanya, melalui unsur-unsur musik yaitu irama, melodi, harmoni, bentuk atau struktur lagu dan ekspresi menurut Arini dikutip (Setiawan Yohanes, p. 3).

Musik merupakan sesuatu yang nyata dan selalu hadir dalam kehidupan manusia. Alam tercipta kaya akan nuansa dan irama musik, unsur musik yang berasal dari alam yaitu, suara angin, gemercik air hujan, sungai yang jatuh, suara ombak dilaut. Alam mengajarkan manusia dengan keharmonisan, keseimbangan, simetris, sistematis, dan rasa kebersamaan dan penyatuan melalui irama, dan bunyibunyian alamiah. Manusia tidak akan pernah bisa lepas dari bunyi-bunyian yang terdengar setiap detik dengan variasi jenis, frekuensi, durasi, tempo dan irama. Masing-masing memiliki kekhasan musik alaminya tersendiri. Tubuh manusiapun memiliki bunyi dan irama, denyut jantung, dan pita suara yang dpat diatur sesuai dengan keinginan manusia sehingga semakin memperkuat posisi penting dlaam kehidupan manusia.(Yeni dan Euis, 2017)

Jenis permainan edukatif yang di terapkan dapat dibedakan menjadi dua yaitu permainan yang membutuhkan aktivitas fisik(bermain aktif) dan dan yang sedikit membutuhkan permainan fisik (bermain pasif). a) permainan dominan fisik atau bermain aktif yaituyang menguras cukup energi anak 
dalam melakukan permainan misalnya bermain bebas bernyanyi, menari dan bermain musik, drama, olahraga, larilarian.b) permainan dominan nonfisik permainan tidaqk membutuhkan energi yang terlalu besar misalnya menulis, membaca, mewarnai, menonton tv, mendengar radio (Hijriati, p. 62-63).

Musik menurut (AT. Mahmud, 1995) adalah aktivitas kreatif. Seorang anak yang kreatif, memiliki rasa ingin tahu yang tinggi, sikap selalu ingin mencoba, dan memiliki daya imajinasi. Wujud sesuatu yang kreatif disebut pula kreativitas. Pada kegiatan berkreasi, proses tindakan kreativitas lebih diutamakan kepentingannya dari pada hasil yang dicapai. Karena pada proses itulah daya imajinasi, rasa ingin tahu, sikap ingin mencoba, berkembang dan dikembangkan guna melahirkan suasana khas terhadap penyajian musik atau nyanyian.

Sebagaimana yang telah diketahui, otak manusia terbagi menjadi atas belahan otak kiri dan otak kanan. Belahan otak kiri umumnya mengurusi tubuh bagian kanan, dan sebaliknya otak kanan mengurusi tubuh bagian kiri. Otak kiri lebih banyak mengendalikan aktivitas bersifat analisis seperti kegiatan matematika, logika, dan kemampuan bahasa. Sedangkan otak kanan lebih banyak mangandalikan kegiatan presepsi seperti imajinasi, melamun, melukis, musil, dan irama/ritme.

Dari penelitian terakhir, ternyata musik (khususnya klasik) dapat melibatkan kedua belahan otak kiri dan kanan. Karena aktivitas musik dapat menggabungkan fungsi analisis dengan fungsi kreatif sekaligus. Kegiatan kreativitas di bidang musik menurut (Yeni dan Euis, 2017) bertujuan memantapkan dan mengembangkan pengetahuan dan keterampilan musik yang telah diperoleh, antara lain:

1. Melatih kepekaan rasa dan emosi yng dimiliki anak.

2. Melatih mental anak untuk mencintai keserasian, keharmonisan, keindahan, dan kebaikan.

3. Mencoba dan memilih alat musik yang sesuai untuk mengungkapkan isi atau maksud pikiran atau perasaan.

4. Meningkatkan kemampuan mendengar pesan dan menyelaraskan gerak terhadap musik yang didengar.

5. Meningkatkan kemampuan mendengar musik atau nyanyian dengan mengamati sifat, watak, atau ciri khas unsur pokok musik, dan 
6. Meningkatkan kepekaan terhadap isi pesan musik atau nyanyian untuk dapat menikmati dan menghargai musik atau nyanyian.

Alat-alat permainan edukatif yang dikembangkan harus memiliki berbagai fungsi dalam mendukung penyelenggaraan proses belajar anak sehingga kegiatan dapat berlangsung dengan baik dan bermakna serta menyenangkan bagi anak (Baik Nilawati Astini, dkk, pp. 33-34). Fungsi-fungsi alat permainan edukatif tersebut adalah sebagai berikut:

a. Menciptakan situasi bermain (belajar) yang menyenangkan bagi anak sehingga dalam proses pemberian stimulasi indikator kemampuan anak bisa tercapai.

b. Menumbuhkan rasa percaya diri dan membentuk kepribadian diri anak yang positif. c. Memberikan stimulus dalam pembentukan perilaku dan pengembangan kemampuan dasar. APE dapat membantu anak dalam pembentukan perilaku melalui pembiasaan dan pengembangan kemampuan dasar, sehingga Alat permainan edukatif dirancang dan dikembangkan untuk memfasilitasi kedua aspek pengembangan tersebut.

d. Memberikan kesempatan bagi anak untuk bersosialisasi, berkomunikasi dengan teman sebaya. Sehingga alat permainan edukatif berfungsi memfasilitasi anak-anak mengembangkan hubungan yang harmonis dan komunikatif dengan lingkungan yang ada disekitar misalnya dengan teman-temannya.

\section{Gambaran Umum Paud 'Aisyiyah Terpadu Gantiwarno}

Paud 'Aisyiyah Terpadu

Gantiwarno didirikan pada tanggal 1 Juni 2008 oleh Pimpinan Cabang 'Aisyiyah Gantiwarno. Pendidik dari tahun ketahun dijabarkan dalam table berikut.

Tabel.1 Pendidik Paud 'Aisyiyah Terpadu Gantiwarno

\begin{tabular}{|c|ll|}
\hline TA & \multicolumn{1}{|c|}{ Pendidik } \\
\hline $2008 / 2009$ & $\begin{array}{l}\text { 1. } \\
\end{array}$ & Erna Kusumaningrum \\
& 2. Suryani \\
\hline
\end{tabular}




\begin{tabular}{|c|ll|}
\hline & 3. & Siti Mahmudah \\
& 4. & Utami Budi Wahyuni \\
& 5. & Restu Trimulyani \\
\hline $2009 / 2010$ & 1. & Erna Kusumaningrum \\
& 2. & Utami Budi Wahyuni \\
& 3. & Restu Trimulyani \\
& 4. & Sri Rahayu \\
& 5. & Tri Prasetyani \\
\hline $2010 / 2011$ & 1. & Erna Kusumaningrum \\
& 2. & Utami Budi Wahyuni \\
& 3. & Restu Trimulyani \\
& 4. & Sri Rahayu \\
\hline $2011 / 2012$ & 5. & Tri Prasetyani \\
\hline sampai & 1. & Erna Kusumaningrum \\
dengan TA & 3. & Restu Trimulyani \\
$2016 / 2017$ & 4. & Sri Rahayu \\
& 5. & Ulfah Tri Puji Astuti \\
\hline $2017 / 2018$ & 1. & Erna Kusumaningrum \\
& 2. & Restu Trimulyani \\
& 3. & Sri Rahayu \\
& 4. & Siti Chosiyatun \\
& 5. & Ika Sariningsih \\
\hline $2018 / 2019$ & 1. & Erna Kusumaningrum \\
& 2. & Restu Trimulyani \\
3. & Sri Rahayu \\
4. & Siti Chosiyatun \\
& 5. & Ika Sariningsih \\
\hline
\end{tabular}

Pada awal berdiri bangunan yang digunakan untuk kegiatan peserta didik menyewa dari salah satu pengurus yang berada di wilayah dukuh Baturan, Desa Baturan kecamatan Gantiwarno Klaten. Dalam perkembangannya pada tahun 2010 mulai dibangun gedung baru dengan dana swadaya dari yayasan dan tahun 2011 mendapatkan 1 unit gedung baru untuk TK Pedesaan dari Dirjen Paud. Gedung baru yang berada di Dukuh Birin, Desa Mlese, kecamatan Gantiwarno mulai ditempati pada tahun ajaran 2012/2013. Pada tahun 2014 mendapatkan bantuan 2 ruang kelas dan masjid dari donatur.

Paud 'Aisyiyah sebagai lembaga terpadu membuka layanan usia 0-6 tahun untuk Taman Penitipan Anak, Kelompok Bermain dan Taman Kanakkanak yang berada dibawah satu manajemen Paud 'Aisyiyah Terpadu Gantiwarno Klaten. Tahun ajaran 2018/2019 lembaga memiliki 51 peserta didik dan 5 pendidik. 
Tabel.2 Prestasi-prestasi yang pernah didapatkan

\begin{tabular}{|l|l|l|}
\hline Tahun & \multicolumn{1}{|c|}{ Prestasi } & \multicolumn{1}{c|}{ Tingkat } \\
\hline 2009 & Penampil terbaik II Dolanan Tradisional & Kabupaten Klaten \\
\hline 2012 & Juara II Lomba Karya APE & Kabupaten Klaten \\
\hline 2012 & Juara II lomba menyusun balok & Kawedanan Gondang \\
\hline 2014 & Juara I lomba Finger Painting & Kec. Gantiwarno \\
\hline 2014 & Juara III Lomba Geguritan & Kec. Gantiwarno \\
\hline 2014 & Juara II Lomba Bermain sambil Bernyanyi & Kec. Gantiwarno \\
\hline 2014 & Juara II Lomba Menyusun Geometri & Kec. Gantiwarno \\
\hline 2014 & Juara II Lomba Lari Bendera & Kec. Gantiwarno \\
\hline 2015 & Juara I Lomba Bercerita dengan Gambar & Kec. Gantiwarno \\
\hline 2015 & Juara II Lomba Lari Memindahkan Bendera & Kec. Gantiwarno \\
\hline 2016 & Juara II Lomba Gebyar Paud & Kec. Gantiwarno \\
\hline 2017 & Juara I Lomba bergerak sesuai irama & Kec. Gantiwarno \\
\hline 2017 & Juara II Lomba gerak dan lagu dolanan & Kec. Gantiwarno \\
\hline 2018 & $\begin{array}{l}\text { Juara Harapan II lomba drunband pra } \\
\text { mandiri A KODAK }\end{array}$ & Kab Klaten \\
\hline 2018 & $\begin{array}{l}\text { Juara I colorguard lomba drunband } \\
\text { pramandiri A KODAK }\end{array}$ & Kab Klaten \\
\hline 2018 & $\begin{array}{l}\text { Juara III Paramanandi lomba drunband } \\
\text { pramandiri A KODAK }\end{array}$ & Kab Klaten \\
\hline 2018 & Juara III Lomba menyusun Balok & Kec. Gantiwarno \\
\hline 2018 & Juara II Lomba bercerita dengan Gambar & Kec. Gantiwarno \\
\hline & \multicolumn{2}{l}{} \\
\hline
\end{tabular}

Tabel.3 Data Sarana dan Prasarana

\begin{tabular}{|c|c|c|c|}
\hline \multicolumn{4}{|c|}{ Jenis Ruang, Jumlah dan Luasnya } \\
\hline No & Jenis Ruang & Jumlah & Luas (m2) \\
\hline 1. & Ruang Kelas & 4 & 124 \\
\hline 2. & Ruang Tamu & 1 & 9 \\
\hline 3. & Ruang Admisinstrasi & 1 & 9 \\
\hline 4. & Perpustakaan & 1 & 30 \\
\hline 5. & UKS & 1 & 9 \\
\hline 6. & Ruang Makan & 1 & 18 \\
\hline 7. & Kamar Mandi & 4 & 9 \\
\hline 8. & Dapur & 1 & 9 \\
\hline 9. & Gudang & 1 & 18 \\
\hline 10. & Masjid & 1 & 81 \\
\hline \multicolumn{4}{|c|}{ Luas Tanah (Milik) : $1100 \mathrm{~m} 2$} \\
\hline \multicolumn{4}{|c|}{ Luas Bangunan : $300 \mathrm{~m} 2$} \\
\hline \multicolumn{4}{|c|}{$\begin{array}{l}\text { Jumlah Buku Perpustakaan : } \\
\text { a. Buku Perpustakaan Anak : } 250 \text { buah } \\
\text { b. Buku Perpustakaan Guru : } 100 \text { Buah }\end{array}$} \\
\hline \multicolumn{4}{|c|}{ Jumlah dan Jenis Muebeler: } \\
\hline N0 & Jenis Meubeler & Jumlah & Kondisi \\
\hline 1. & Meja Guru & 3 & Baik \\
\hline 2. & Kursi Guru & 3 & Baik \\
\hline 3. & Meja Anak & 10 & Baik \\
\hline 4. & Kursi Anak & 40 & Baik \\
\hline 5. & Lemari inventaris & 2 & Baik \\
\hline 6. & Rak administrasi & 3 & Baik \\
\hline 7. & Rak buku perpustakaan & 2 & Baik \\
\hline 8 & Rak APE & 12 & Baik \\
\hline 9 & Rak sepatu & 7 & Baik \\
\hline
\end{tabular}




\begin{tabular}{|c|c|l|c|}
\hline 10 & Papan Tulis & \multicolumn{1}{c|}{5} & \multicolumn{1}{c|}{ Baik } \\
\hline \multicolumn{2}{|c|}{ Alat Peraga dan Bermain } & \multicolumn{1}{|c|}{} \\
\hline 1. & Dalam Ruangan & $\begin{array}{l}\text { Puzle, boneka, alat dokter-dokteran, } \\
\text { mainan masak-masakan yang terbuat dari } \\
\text { plastik, beserta buah-buahan dan sayuran, } \\
\text { permainan bangun ruang yang terbuat } \\
\text { dari kayu, orkestra musik, kotak kartu } \\
\text { musik, dan gendang kecil. }\end{array}$ \\
\hline 2. & Luar Ruangan & $\begin{array}{l}\text { Jaring laba-laba, bola dunia, gua } \\
\text { petualang,papan titian, jungjat jungkit, } \\
\text { mangkok putar, jarring laba-laba tinggi, } \\
\text { perosotan, ayunan, gawang bola, } \\
\text { kerangjang bola basket, mandi bola, } \\
\text { jembatan goyang }\end{array}$ \\
\hline
\end{tabular}

\section{Deskripsi Peranan Alat Permainan Edukatif Dalam Pengembangan Kreativitas Musik Anak}

Berdasarkan hasil observasi yang dilakukan di PAUD Aisyiyah Terpadu Gantiwarno, kegiatan dimulai pada pukul 08.00-12.00 wib. Pada hari tersebut mewawancarai kepala sekolah yaitu ibu Erna Kusumaningrum, S. Pd terkait dengan sejarah berdirinya PAUD Aisyiyah Terpadu Gantiwarno, dan alat permainan apa saja yang dimiliki sekolah dalam mengembangkan kreativitas musik anak. Sebelum anak memulai aktivitas bermain, anak-anak melakukan aktivitas untuk melatih fisik motorik anak, yaitu berbaris dan bernyanyi sambil melakukan gerakan lompat-lompat sederhana. Setelah melakukan aktivitas melatih fisik motorik anak, kemudian anak masuk kedalam kelas untuk berdoa sebelum melakukan aktivitas belajar sambil bermain.
Sebagian besar alat permainan edukatif yang ada di PAUD Aisyiyah Terpadu Gantiwarno, berbahan dasar dari barang-barang bekas yang ada dilingkungan sekitar. Guru dan anakanak berkerjasama dalam memanfaatkan barang-barang bekas ini menjadi suatu alat permainan edukatif yang dapat menstimulasi kreativitas musik anak. Barang-barang bekas ini terdiri dari, ember, panci, kaleng, botol, kardus atau kotak bekas. Adapun beberapa bahan-bahan alam yang juga dimanfaatkan dalam membuatalat permainan edukatif yaitu seperti, pasir, batu kerikil, dan biji-bijian kering. Berikut adalah beberapa aktivitas melalui alat permainan edukatif di PAUD Aisyiyah Terpadu Gantiwarno yang dapat mengembangkan kreativitas musik anak:

\section{a. Orkestra Musik Perasaan}


Kegiatan:

1. Guru dan anak-anak bersamasama menyiapkan semua alatalat musik yang dapat dimainkan seperti ember panci, kaleng bekas, botol dan lain sebagainya.

2. Setelah guru menyiapkan semua alat-alat musik, lalu anak-anak memainkan alat musik tersebut sesuai dengan keinginan atau minat mereka.

3. Kemudian guru memberikan intruksi untuk memainkan alat musik

Guru mengatakan "ayo anakanak coba buatlah bunyi sedih", "ayo anak-anak coba nyanyikan lagu gembira”, “ayo anak-anak coba buatlah bunyi marah".

4. Setelah guru telah memberikan contoh, lalu guru meminta seorang anak untuk menjadi dirigen untuk memimpin orkestra musik perasaan temantemannya.

Berdasarkan observasi dan wawancara yang dilakukan peneliti dengan guru kelas, bahwa dengan kegiatan bermain menggunakan alat permainan edukatif, "Orkestra Musik Perasaan", meningkatnya kemampuan berfikir kreatif imajinasi anak dalam menciptakan alat permainan edukatif untuk kreativitas musik, dan anak-anak dapat mengekspresikan kepekaan perasaaannya melalui alat musik yang dimilikinya.

\section{b. Kotak Kartu Musik}

Kegiatan:

1. Guru menyiapkan kotak bekas atau kardus bekas khusus untuk menyimpan kartu musik, dan karton yang telah dipotongpotong sesuai ukuran untuk menuliskan judul lagu dan gambar dari judul lagu tersebut.

2. Setiap anak-anak mulai belajar lagu baru, guru membuat sebuah kartu dengan menuliskan judul lagu di atasnya dan sebuah gambaran yang berkaitan lagu tersebut dibaliknya.

3. Sebagai contoh pertama yaitu lagu "Balonku”, guru menggunakan gambar lima balon warna-warni sebagai klu untuk judul lagu "Balonku”, contoh kedua yaitu lagu "Nina Bobo", guru menggunakan gambar anak perempuan sedang tidur sebagai klu untuk judul lagu "Nina Bobo".

4. Untuk mengembangan kreativitas anak selanjutnya, guru meminta anak-anak sendiri untuk membuat gambar-gambar 
tentang lagu yang diajarkan.

Anak-anak dapat menggambar bebas sesuai dengan imajinasinya sendiri.

5. Kegiatan selanjutnya guru menyiapkan kartu-kartu yang telah dibuat judul lagu dan klu gambar dari lagu tersebut dalam sebuah kotak.

6. Sekali-sekali, guru memperlihatkan kepada anakanak sebuah kartu dari dalam kotak, kemudian guru bertanya kepada anak-anak kira-kira gambar tersebut menceritakan tentang apa judul lagunya, kemudian anak menyanyikan lagu tersebut bersama-sama.

Berdasarkan observasi dan wawancara yang dilakukan peneliti dengan guru kelas, bahwa dengan kegiatan bermain menggunakan alat permainan edukatif "Kotak Kartu Musik", anak-anak dapat lebih cepat mengingat lagu-lagu yang telah dinyanyikan tadi, berfikir asosiasi, dan berfikir kreatif. Anakanak sangat menyukai kegiatan menebak judul lagu ini, anak-anak senang karena gambar yang mereka buat berguna dan dihargai oleh guru dan anak-anak lainnya.

c. Perkusi Bernyanyi
Kegiatan:

1. Guru bersama anak-anak, menyiapkan bahan-bahan yang diperlukan, seperti kaleng bekas minuman, plastik atau karton bekas susu, karet gelang, kertas roti, batu kerikil atu pasir dan biji-bijian kering.

2. Guru memberikan penjelasan kepada anak-anak bagaimana membuat perkusi yaitu kaleng bekas dibersihkan dan permukaannya diratakan. Kaleng tersebut diisi dengan batu kerikil, pasir, atau biji-bijian (anak-anak bebas untuk memilih dan mencari). Kaleng tersebut kemudian ditutup dengan kertas atau plastik dan diikat dengan karet.

3. Anak-anak dapat menghiasi alat musik tersebut sesuai dengan keinginan mereka.

4. Setelah selesai maka kegiatan bermain perkusi buatan siap dimainkan.

5. Guru bersama anak-anak memainkan alat musik yang baru dibuat sambil menyanyikan lagu. Lagu yang diiringi perkusi tersebut dapat divariasikan secara bergantian atau saling bersahutan antara perkusi yang memiliki suara yang sama 
dengan perkusi yang berbeda bunyi yang dihasilkannya.

6. Guru dapat bertanya kepada anak tentang ide permainan lain yang ingin mereka mainkan dengan perkusi tersebut.

Berdasarkan observasi dan wawancara yang dilakukan peneliti dengan guru kelas, bahwa dengan kegiatan bermain menggunakan alat permainan edukatif "Perkusi Bernyanyi”, anak-anak dapat membuat alat perkusi dan dapat mengembangkan kreativitas dalam membuat lagu dan bermusik gaya pribadi.

\section{d. Soneta Cilik}

1. Guru menyiapkan tamtam atau gendang kecil, gitar kecil, suling bambu, dan piano mainan.

2. Guru membagi anak-anak dalam beberapa kelompok.

3. Setiap anggota kelompok memegang alat musik masingmasing sesuai dengan keinginannya.

4. Guru menanyakan kepada anak siapa yang mau untuk berperan sebagai penyanyi yang menyanyikan sebuah lagu. Anak-anak lain mengiringi lagu dengan alat musik yang dipegangnya.
5. Kegiatan dilakukan dengan bergantian.

Berdasarkan observasi dan wawancara yang dilakukan peneliti dengan guru kelas, bahwa dengan kegiatan bermain menggunakan alat permainan edukatif "Soneta Cilik", meningkatnya kemampuan anak dalam bernyanyi, dan anak gembira saat melakukan kegiatan ini.

\section{KESIMPULAN}

Pada dasarnya, setiap orang memiliki potensi untuk kreatif, namun yang perlu digaris bawahi adalah bagaimana untuk mengembangkan kemampuan yang masih bersifat potensi tersebut. Salah satunya adalah kreativitas musik. Kreativitas bukan kemampuan bawaan dari lahir, tetapi merupakan kemampuan yang dapat dipelajari dan dikembangkan. Kreativitas musik penting untuk dikembangkan karena kreativitas musik berpengaruh terhadap kehidupan seseorang, misalnya kreativitas berpengaruh terhadap perasaan seseorang, kepekaan emosi, dan mental seseorang. Bayangkan apa jadinya jika tidak ada musik di hidup kita? tentu saja hidup kita akan terasa hampa. Sebaliknya peranan kreativitas terhadap anak sangatlah penting, karena kreativitas musik juga dapat 
mendukung tumbuh kembang anak menjadi pribadi yang memiliki jiwa bermusik.

Anak usia dini merupakan golden age yakni usia emas yang merupakan pondasi bagi perkembangan di usia selanjutnya. Pengembangan kreativitas musik nak usia dini dapat dilakukan dengan berbagai cara, salah satunya yaitu dengan alat permainan edukatif. Seperti yang kita ketahui bahwa bermain adalah dunia anak. Alat permainan edukatif yang digunakan untuk mengembangkan kreativitas musik anak haruslah sesuai dengan tingkat perkembangan anak. Suasana yang menyenangkan juga dapat mendukung proses pengembangkan kreativitas musik anak sehingga anak tidak merasa bosan dengan kegiatan yang dilakukan.

Berdasarkan analisis data-data dari observasi dan wawancaraa secara keseluruhan ada banyak alat permainan edukatif yang dapat mengembangkan kreativitas bermusik anak seperti, orkestra musik perasaan, kotak kartu musik, perkusi bernyanyi, dan soneta cilik. Semua kegiatan tersebut memiliki pengaruh yang sangat besar dalam mengembangkan kreativitas bermusik anak. Saran peneliti untuk selanjutnya diharapkan PAUD ini dapat mengembangkan alat permainan edukatif yang mereka cipatakan tidak hanya di satu bidang pengembangan saja, melainkan bidang-bidang pengembangan yang lainya.

\section{DAFTAR PUSTAKA}

Baik Nilawati Astini, Nurhasanah, Ika Rachmayani, I Nyoman Suarta. (2017). "Identifikasi Pemafaatan Alat Permaian Edukatif (APE) Dalam Mengembangkan Motorik Halus Anak Usia Dini”. Jurnal Pendidikan Anak, Volume 6, Edisi 1, Juni.

Habsari, Sri. (2005). Bimbingan dan Konseling SMA untuk Kelas XI. Jakarta: Grasindo.

Hijriati. (2017). "Peranan Dan Manfaat Ape Untuk Mendukung Kreativitas Anak Usia Dini”. Jurnal Ar-Raniry, Volume III. Nomor 2. Juli-Desember"

Lexy J. Moleong. (2010). Metodologi Penelitian Kualitatif, Bandung: PT. Remaja Rosdakarya.

Milyartini, R. (2009). Evaluasi Pendidikan Musik". Bandung: Bintang Wali Artika.

Nur Ahmadi Bi Rahmani. (2016). Metodologi Penelitian Ekonomi. Medan: FEBI UIN-SU PRESS. https://scholar.google.co.id/citatio ns?user=yVzuORQAAAAJ\&hl=i d

Setiawan Yohanes. (2016). Pengembangan Kreativitas Musik Dalam Pembelajaran Seni Budaya (Musik) Di SMA Negeri Pati 1. Jurnal Seni Musik Volume 5 nol.

Syamsuardi. (2012). "Penggunaan Alat Permainan Edukatif (APE) Di Taman Kanak-Kanak Paud Polewali Kecamatan Tanete 


\section{Riatang Kalimatan Barat Kabupaten Bone". Jurnal Publikasi, Volume II No. 1 Februari-Mei.}

Syamsuardi. (2012). "Penggunaan Alat Permainan Edukatif (Ape) Di Taman Kanak-Kanak Paud Polewali Kecamatan Tanete Riattang Barat Kabupaten Bone", Jurnal Publikasi, Volume II No. 1 Februari-Mei.

Yeni Rachmati dan Euis Kurniati. (2017). Strategi Pengembangan Kreativitas Pada Anak Usia Taman Kanak-Kanak. Jakarta: PT Kharisma Putra Utama, 2017), Cetakan ke-4. Hlm 63.

Zujadi, Ansor. (2010). "Penciptaan Musik Melalui Teknik Eksplorasi Bunyi Sebuah Bentuk Pendidikan Kreatif". Ritme Jurnal Seni dan Pengajarannya, Vol. 8. 